\title{
The Ecosystem of VAT Administration in E-Commerce: Case of the Eastern Europe Countries
}

\author{
ALLA ABRAMOVA ${ }^{1}$, KOSTIANTYN SHAPOSHNYKOV ${ }^{2}$, ARTUR ZHAVORONOK*3, \\ PAVLO LIUTIKOV ${ }^{4}$, ILLIA SKVIRSKYI ${ }^{5}$, OLEKSANDR LUKASHEV ${ }^{6}$ \\ ${ }^{1,3}$ Department of Public, Corporate Finances and Financial Intermediation, YURIY FEDKOVYCH CHERNIVTSI \\ NATIONAL UNIVERSITY, CHERNIVTSI, UKRAINE. *E-mail: a.zhavoronok@chnu.edu.ua \\ ${ }^{2}$ Director of Black Sea Research Institute of Economy and Innovation, ODESA, UKRAINE. \\ ${ }^{4,5}$ Department of Administrative and Customs Law, UNIVERSITY OF CUSTOMS AND FINANCE, DNIPRO, UKRAINE. \\ ${ }^{6}$ Department of Financial Law, YAROSLAV MUDRYI NATIONAL LAW UNIVERSITY, KHARKIV, UKRAINE
}

\begin{abstract}
Quarantine economic conditions put forward new demands to tax administration's efficiency as a priority source of the EU financial resources. The relationship between fair, efficient, sustainable taxation and budget revenues' adequacy to finance social and economic investment, innovation, and development needs is evident. Therefore, ensuring tax administration's efficiency and effectiveness in any EU country is of theoretical and practical importance.

The study aims to deepen the theoretical and applied provisions of the VAT administration in e-commerce operations in a global convergence of the national economic systems. The analysis of the state and forecast of the VAT mobilization in the EU countries' e-commerce operations are presented. The research's specific is to assess the VAT tax base's future size in the context of changes in the EU tax legislation. According to the scientific literature analysis, in the framework of forecasting the studied tax, it is advisable to use econometric forecasting methods based on time series models.

As the result of the study, the forecast volumes of the VAT base of Eastern Europe and the amount of approximate future tax revenues are presented. The obtained results confirm the relationship between the growth of e-commerce and VAT tax revenues under such transactions. It led to the presentation of the author's vision of the VAT administration ecosystem for e-commerce transactions and the allocation of its functional entities.

The directions on achieving the maximum volumes of the VAT mobilization following the EU tax legislation requirements in European integration and globalization were substantiated. The submitted conclusions are entitled to be used in tax administration processes in the matters of forecasting other tax payments.
\end{abstract}

Keywords: tax administration, VAT, fiscal stimulus, e-commerce.

JEL Classification: F02; F63; H21; H22; 011

Received: 2 April 2021

Accepted: 6 April 2021 


\section{Introduction.}

The changing social and economic conditions of the global development at the end of 2019-2020 require ensuring the efficiency and guarantee of the fiscal system functioning in any country. Globalization processes, digitalization, modernization of the business models (Dubyna et al., 2021; Kharazishvili et al., 2020; Vovk et al., 2020; Skarlet et al., 2020; Popelo et al., 2020; Kwilinski et al., 2020) determine the need to adapt the tax administration of the EU countries to them by ensuring the adequacy and completeness of each country's revenue base on the grounds of minimizing the shadow economy, expanding the tax base, optimizing the key tax instruments. These conditions necessitate continuous improvement and consolidation of the $\mathrm{EU}$ tax administration to various challenges on tax transparency, including through the rapid development of business and trade on the Internet.

Examining the indicators of the tax payments mobilization (about $33,8 \%$ of GDP) to the budgets of the European countries (EU-28), a significant share in their structure of consumption taxes, in particular, the VAT (about 11\% of GDP) based on the Eurostat data is noted (Fig. 1).

Figure 1. Dynamics of VAT revenues indicators in the EU countries

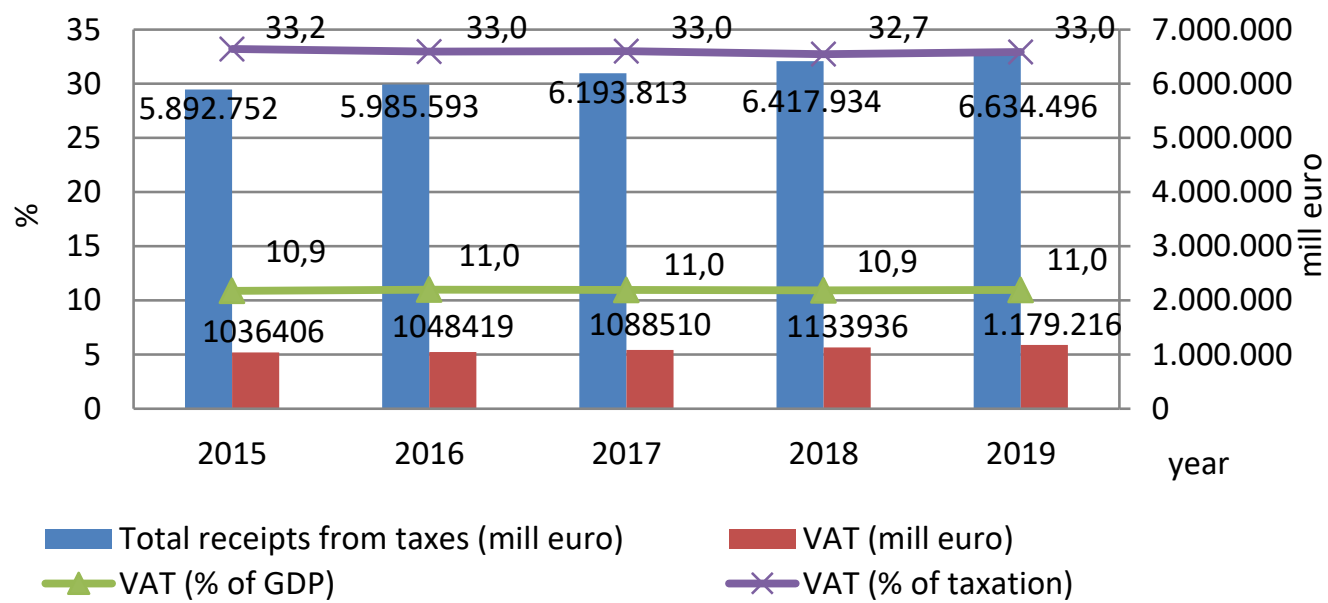

Source: Own study based on Eurostat Database (2020)

The state of the market for the consumption of goods and services plays a decisive role in the VAT mobilization in the EU countries (Czyżewski et al., 2019; Dzwigol, Dzwigol-Barosz, 2020; Saługa et al., 2029). Today, VAT is a stable source of income and determines the efficiency of tax collection. During the last reporting periods, a special place in the structure of trade turnover began to occupy ecommerce with its steady growth trends (EU-28) based on the Digital single market - promoting ecommerce for individuals.

According to the provisions of the European Statistics Commission and OECD, e-commerce is the sale or purchase of goods or services by businesses, households, individuals or private enterprises through electronic transactions carried out via the Internet or other computer means (the Internet networks).

Based on the Statista data, the total retail e-commerce revenue in Europe in 2020 made euro 330,79 billion. The basis of such activity according to the data of e-commerce industry in Europe - Statistics \& Facts of Official site of the Statista is the constant growth to the Internet access (90\% - in 2020) and the share of Internet shopping (67\% - in 2020). The performance of digital platforms is constantly growing and will grow faster in the future. We'd like to note that trades based on such platforms do not always fall into the field of taxation and, as a result, are not properly taxed.

The total GDP of the EU (EU-28), which grew in 2020 and amounted to about euro 12,6 trillion by the International Monetary Fund data, is the base for increasing online shopping in Europe, in particular, under quarantine economic conditions. At the same time, buyers' behavior and national habits determine the differentiated economic and social maturity of the EU countries, which is different in current conditions (Boiko et al., 2019). 
The following indicators represent the volumes of e-commerce in the EU countries by regional distribution: Western Europe - 70\%, Southern Europe - 15\%, Northern and Central Europe - 7\% accordingly, Eastern Europe - only 1\%. Particular differentiation is inherent in Eastern and Western Europe (Great Britain is a leader of e-commerce - B2C), where $70 \%$ and $36 \%$ of Internet users, respectively, make purchases online. The presented e-commerce turnovers and GDP growth of the European countries determine the formation of the unused base of e-commerce taxation and determine the need for a professional response in such an area of public administration as tax administration.

The first steps to meet market challenges were amendments to the EU tax legislation in the field of VAT, including taxation of the online markets, digital platforms and online sellers on the principle of the taxation - the location of the consumer with the elimination of the benefits for tax of the low-cost purchases (not higher EUR 22,00), according to the Council Directive (EU) 2019/1995. It is vital to resolve issues related to the exchange of tax information between tax administrations and online sales entities, strengthening the requirements for cross-border sellers to prevent tax evasion and shadowing the VAT tax base.

\section{Literature review.}

At all stages of the evolution of tax relations, tax administration was interpreted as the creation of conditions for voluntary fulfillment of tax obligations, accordingly, the payment of taxes and fees, and in case of non-compliance with the law-the application of appropriate penalties. Its main goal was and is to achieve efficiency (low cost of taxation) and effectiveness (completeness of the mobilization of tax obligations) of the tax system functioning (Grigoraș-Ichim et al., 2018; Ivashchenko et al., 2017; Bondarenko et al., 2020; Kholiavko et al., 2020).

Today, the European Commission determines the tax authorities' activities under tax administration to collect tax revenues reasonably and efficiently with limited costs for taxpayers and the tax administration itself. With the VAT introduction in 1954 in France and more than 140 countries globally, it became a more evident example of the consolidation of tax policy in the twentieth century (Hodzic et al., 2017). As noted by Cheng L. (2011), the VAT introduction became the most critical event in the evolution of taxes in the second half of the twentieth century. These tax field changes led to the formation of the public administration sphere - VAT tax administration in each of the countries.

The first steps towards understanding the need to increase VAT administration efficiency were made in the 90s of the twentieth century under the vector of the application of computerized tax collection systems (Andriyash, 2014; Cosmulese et al., 2019). This approach was based on large amounts of information data, which need to be processed quickly and efficiently and identify those economic entities that have avoided compliance with the VAT tax liability for various reasons. Today, there is no doubt about the VAT's key role in electronic data processing administration (Killington et al., 2017; Kovova et al., 2018; Lamensch, 2017; Spies, 2017).

We share the point of view of Lagovska O. (2020), Rini E. (2020), Tanzi V. (2000) and Tymchenko O. (2019) that the vast amount of tax information in the elements of globalization processes form the socalled "global mobile tax bases". As a result, cross-border mobility destroys national tax bases and reduces each country's fiscal authorities and tax administration's efficiency, in particular. Lodin S. (2002) believes that under such conditions, its incompletely defined legal limits lead to the possibility of such trade operations without paying income taxes and value-added tax evasion and under receipt of significant tax revenues to the budget of e-commerce countries.

Mattson R. (1997) established the basis of arguing a set of challenges in the field of e-commerce taxation - "The Internet is borderless and unmanaged, and the consumers and companies can use cyberspace as a vehicle to avoid taxation". An attempt was made to prove the assumption that audit trials will disappear in cyberspace or that it will be impossible to verify the participants in a particular transaction. However, the development of indirect tax administration has demonstrated the ability to identify transactions, the participants involved in e-commerce transactions, and their physical location. 
The OECD presents similar statements.

The nature of e-commerce, peculiarities of its implementation in current conditions (Rivza et al., 2020), the rate of increase in its turnover, problems of the VAT shortcomings in e-commerce operations in the structure of the EU budget deficit, and, finally, the revision of customs policy has recently become a point of study for many tax administrators according to Article 287(4), second subparagraph, TFEU. New legislative rules and features of the tax regime for cross-border e-commerce transactions (B2C supplies) of VAT have found a theoretical and practical discussion in the book of Kesteren G., Cornielle S. \& Nellen F. The Basis of Legislation on the EU VAT.

Kurniawan T. (2018) and Merkx M. (2020) believe that the modernization of the VAT tax administration of e-commerce transactions should be developed and implemented in such areas as the organizational structure, a business process and information and communication technologies, people and resources management. Oliychenko I. (2020) and Scarcella L. (2020) notes that the European Community, led by governing bodies, is obliged to work comprehensively to eliminate problematic issues and losses in the VAT administration e-commerce transactions.

As part of forecasting future VAT revenues, including in the EU, as a result of changes in the legal field of e-commerce taxation, scientists and practitioners are increasingly searching for and selecting adequate methods of econometric modeling. Researchers today identify three methods for estimating the VAT base: the aggregate approach, the branch approach, and the "entry-exit" approach (Gamboa et al., 2002; Glenn et al., 2000; Lamensch, 2018).

We share a scientific approach of Kovalenko Y. (2013) and Khudolei V. (2021), who proved the ineffectiveness of the forecasting method by the actual rate (it leads to the decrease in real tax revenue) method of elasticity, the modeling method. Scientists Büyükşahin Ü. \& Ertekin Ş. (2019) also tend to use different forecasting time series methods when using linear and non-linear models alone or in combination. According to them, such a combination can increase the efficiency of forecasting.

As a result of the study, the statement about the close relationship between VAT revenues and its base was considered based on the method of trend and autocorrelation - an econometric method of modeling time series. The result was developing the econometric model of forecasting of tax revenues according to the conditions of changes in the legislation in the short term. The presented model demonstrated the degree of adequacy of the forecast of VAT revenues from e-commerce transactions on the example of Eastern European countries.

Researchers believe that in current conditions, the exchange of information about the objects of ecommerce between the customs authorities of the countries can help deter tax evasion, both from income tax and from VAT. The need for the functioning of VAT information exchange systems in the EU (VIES), the exchange of tax returns, tax invoices, recording of cross-border sales of VAT, as well as the implementation of the border control of e-commerce transactions were investigated in (Liam et al., 2001; Balcerzak, 2016).

Helmuth C. (2000), Papis-Almansa M. (2019) and Shkolnyk I. (2020) consider that the primary way to combat the VAT evasion in the taxation of e-commerce transactions is the introduction of border controls on the movement of goods. Some scholars and practitioners see the need for intermediary agencies to allow the countries to collect VAT on behalf of other members and then redistribute revenues on the assignment base (Gechert et al., 2018; Woon Nam et al., 2003). The need to review the mechanisms of taxation of export/import objects of e-commerce to strengthen the current VAT and stimulate the country's income considering different evasion levels was studied (McLaren, 2013; Kholiavko et al., 2015).

It should be noted that the effective VAT tax administration on e-commerce on the principle of consolidation in the context of globalization should be based on the fair VAT taxation of all economic entities engaged in e-commerce. This grounds tax transparency, fair competitiveness, the absence of ineffective tax measures, and the application of intra-European and internationally agreed tax administration standards to directly prevent losses of national budgets in the EU countries and the EU budget. 


\section{Methodology.}

One of the main tasks of modern economics and practice is analyzing and forecasting various dynamics of the development of all markets' types. At the same time, a special place is occupied by forecasting tax revenues in the tax administration system and, consequently, the implementation of the effective tax policy. The importance of this sphere development is difficult to exaggerate because its reliability depends on the effectiveness of managerial decisions made on its basis.

The study's objective is to determine, in particular, the effectiveness of quantifying VAT tax revenues that can be achieved as a result of the introduction of the total taxation of e-commerce transactions at basic VAT rates in the EU starting from July 2021. As part of this task, it is proposed to forecast the VAT tax base (a priority factor of VAT revenue) and subsequent tax revenues under changes in legislation by using econometric modeling as time series forecasting. The proposed method provides a forecast of the future value or the indicator classification at the specific period. We believe that this form of description is effective by developing programs and areas of management, particularly tax administration, as well as providing recommendations for improving the process under research.

The basis of the study's digital ground is the official statistics of the European Statistical Commission, particularly the results of production, which are modified using the adjustment to the effects of import operations of the selected countries for the study for 2016-2020. The studied countries are Eastern European countries, namely: Bulgaria, Poland, Romania, Slovakia, Hungary and the Czech Republic as the countries with alternatives to the e-commerce development and, accordingly, the VAT's expansion tax base. The research and construction of the econometric model were carried out using the software product "STATGRAPHICS". The total trade volumes were adjusted considering the share in their structure of e-commerce volumes (the percentage determined by Statistics) on the quarter base.

We believe that by forecasting the following two periods (years) of e-commerce, which is defined as the tax base, it is possible to forecast VAT revenues in the future, to identify critical trends and on this basis to develop the practical management proposals and solutions. The formation of the VAT tax base can be predicted using processes. One process means that the volume of e-commerce transactions for the current period correlates with the previous period's tax base (autocorrelation of the first order). The other process means that the deviation (the accidental shock) for the last analyzed period affects the current period's deviation.

In general, the time series or the dynamics series is defined as a sequence of numerical values of the indicator that characterizes the studied social and economic phenomenon's development level. Its nature consists of two main elements: the level of the series (the numerical value of the indicator) (y) and the period $(t)$. This method's peculiarity is the possibility of maximum consideration of possible factors of influence: those that form the main trends (consumption and savings), those that form cyclical fluctuations (cyclical economic development) and random factors. When constructing a time series model, it seems possible to find the sum of these three components (the additive model) or find the derivatives of these components (the multiplicative model). Each of these components will be quantified to build an effective model for forecasting the analyzed indicator. According to the methodology chosen for the application, time series forecasting includes four main stages.

1. Data description - involves the formation of a primary graph of trends, the detection of primary cyclicity, static data and their random nature. The random nature of the data is determined by the autocorrelation process (detection of the data dependence), particularly by the autocorrelation coefficient. A strict requirement for the construction of the model is its diagnosis for its normality and series correlation, resulting in the determination of the autocorrelation coefficient:

$$
r_{1}=\frac{\sum\left(y_{t}-\overline{y_{1}}\right) *\left(y_{t-1}-\overline{y_{2}}\right)}{n \sigma_{y_{t}} \sigma_{y_{t-1}}}
$$

where, as the variable $x$, the levels of the series $y_{t}: y_{2}, y_{3}$ are selected, 
as the variable, the levels of the series $y_{t-1}: y_{1}, y_{2} \ldots$ will be deleted.

The average value is determined as follows:

$$
\begin{gathered}
\overline{y_{t}}=\frac{\sum_{t=2}^{n} y_{t}}{n-1} \\
\overline{y_{t}}=\frac{\sum_{t=2}^{n} y_{t-1}}{n-1}
\end{gathered}
$$

As a result, the autocorrelation function, the correlogram, and the series's structure are revealed.

2. Smoothing. The process allows you to demonstrate the primary trend. One of the main smoothing methods of the time series are moving weighted averages:

$$
W M A=\left(A_{1} * W_{1}+A_{2} * W_{2}+\cdots+A_{n} * W_{n}\right)
$$

where, $A_{n}$ - the data point at the i-period;

$W_{n}$ - the specific weight of the data point in the i-period.

The moving weighted average uses different weights for data points from different periods. As a rule, the weight decreases with each data point from previous periods. At the same time, we'd like to note that the moving average has one drawback - the values at the beginning and end of the series are out of the analysis. For the data at the beginning - that is not so critical, at the same time, for the data, which are at the end of the series, this is more critical, as they influence the future forecast. As a result, a smoothed variable is formed and it seems possible to get rid of sharp bursts.

3. Seasonal decomposition. The process forms a schedule of the series considering the seasonality (sales volume) and the index of the seasonality. There are two models of seasonal decomposition: additive and multiplicative.

The difference is that the multiplicative model represents the seasonality indices in percentage terms and the additive one-in absolute terms.

The seasonality index $I_{S}$ demonstrates the deviations by seasons from the average annual value:

$$
I_{s}=\frac{y_{t}}{y_{s}}
$$

where, $y_{t}$ - average monthly rate for three and more years;

$y_{s}$ - average monthly indicator for all years of the indicator value.

4. Forecast development. The forecast is formed for a certain number of periods, considering the level of significance and probability. The trend equation, graph, and table of forecasted indicators of the studied value are formed.

We believe that the presented method of econometric modeling makes it possible to establish trends in e-commerce in the proposed countries for the planned period (second half of 2021-2022), which can be used to calculate the VAT based on e-commerce. On this basis, it seems possible to forecast for the following two periods ( 2 years) additional, previously unused VAT revenues to Eastern Europe's budgets, the potential of which is relatively high compared to Western Europe.

An attempt was made to develop the VAT ratio (of the 2021-2022 forecasted years) to the total amount of tax revenues (2019) to justify the importance and effectiveness of tax legislation changes relating to VAT on e-commerce transactions. According to the results, this coefficient is calculated as a share of mobilized taxes and fees of the countries selected for the study, which is possible to assert the value of revenues of additional VAT amounts in the forecast period.

\section{Results.}

Following the provisions of the EU Council Directive 2017/2455 and Council Directive (EU) 2019/1995, the direction of the revision of the VAT administration system ("the e-commerce packet 
with VAT"), in particular, under the vector of tax mobilization for cross-border e-commerce transactions of "a business consumer" (B2C) is determined. The main provisions of the innovations concern the single threshold of the mandatory registration of a VAT-payer (EUR 10,000) or the application of a new VAT-OSS.

Table 1. Actual and forecast values of the e-commerce volumes in the countries of Eastern Europe for 2016-

\begin{tabular}{|l|c|c|c|c|c|c|c|}
\hline \multicolumn{1}{|c|}{ Country } & $\mathbf{2 0 1 6}$ & $\mathbf{2 0 1 7}$ & $\mathbf{2 0 1 8}$ & $\mathbf{2 0 1 9}$ & $\mathbf{2 0 2 0}$ & $\mathbf{2 0 2 1}$ & $\mathbf{2 0 2 2}$ \\
\hline Bulgaria & 2007,22 & 2319,72 & 3028,97 & 2537,56 & 4116,59 & 5016,88 & 5152,75 \\
\hline Poland & 36445,66 & 45562,65 & 45100,95 & 61772,00 & 84221,15 & 113022,09 & 113022,1 \\
\hline Romania & 3742,67 & 5527,32 & 4507,60 & 4647,54 & 8646,20 & 12984,796 & 14835,87 \\
\hline Slovakia & 27416,19 & 26276,78 & 33151,52 & 36884,96 & 40915,66 & 61263,4 & 68293,97 \\
\hline Hungary & 22997,28 & 25468,28 & 33253,35 & 43661,07 & 46138,75 & 69431,09 & 78715,18 \\
\hline $\begin{array}{l}\text { Czech } \\
\text { Republic }\end{array}$ & 60774,36 & 67253,25 & 68820,73 & 114872,77 & 113813,37 & 147954,1 & 165544,4 \\
\hline
\end{tabular}

Source: Own study based on Eurostat Database (2020)

It proposed to make an estimated calculation of e-commerce volumes selected for the study of Eastern Europe, and on this basis, to determine future projected VAT revenues to the budgets of the above countries. It makes the possibility to identify the effects of such legislative changes, which, as a consequence, will lead to the restricting of the VAT administration system.

According to the proposed research method, the forecast volumes of e-commerce for the second half of 2021-2022 (Table 1) are presented.

The data in Table 1 establishes the positive forecast trends in e-commerce volumes. Authors believe that this indicator's growth will only be intensified by quarantine social and economic conditions, rapid replacement of P2P for B2C, and the e-commerce process will develop at an accelerated pace and under new requirements of the interaction between buyers and sellers.

The presented forecast values of the VAT base of e-commerce of the studied countries have passed all stages of verification of their adequacy, the level of trust (95\%). The actual and forecast values of the VAT base are shown in Fig. 2.

The presented development scenario is vital for Eastern European countries, as the indicators of their e-commerce development lag far behind other European countries. Thus, the sources of expanding the VAT tax base of these countries are identified.

The proposed methodological approach calculation is based on the average VAT rate of the studied countries (Bulgaria - 20\%, Poland - 23\%, Romania - 19\%, Slovakia - 20\%, Hungary - 27\%, Czech Republic-21\%). According to the EU Directive starting from July 1, 2021, VAT exemptions on imports, including those not exceeding EUR 22,00, will be abolished in all EU member states.

In Poland, such a VAT exemption for e-commerce transactions has already been abolished.

It is not possible to analyze the generalized actual VAT volumes from e-commerce transactions of the EU country for 2016-2020 due to the lack of such statistics.

Thus, using the VAT tax base's initial data (Table 2), we present the estimated indicators of the studied tax in Table 2. It should be noted that the estimated data for 2021 are submitted only for the second half of the year due to the conditions of changes in EU tax legislation.

To strengthen the argumentation of the effectiveness and significance of changes in this EU tax legislation, we consider it appropriate to analyze the share of projected VAT of 2021-2022 concerning the total mobilization of taxes and fees of the surveyed countries 2019 (Fig. 3) to approximate the efficiency. 
Figure 2. The results of forecasting of the VAT tax base of e-commerce transactions in Eastern Europe for 2021-2022 under the time series method

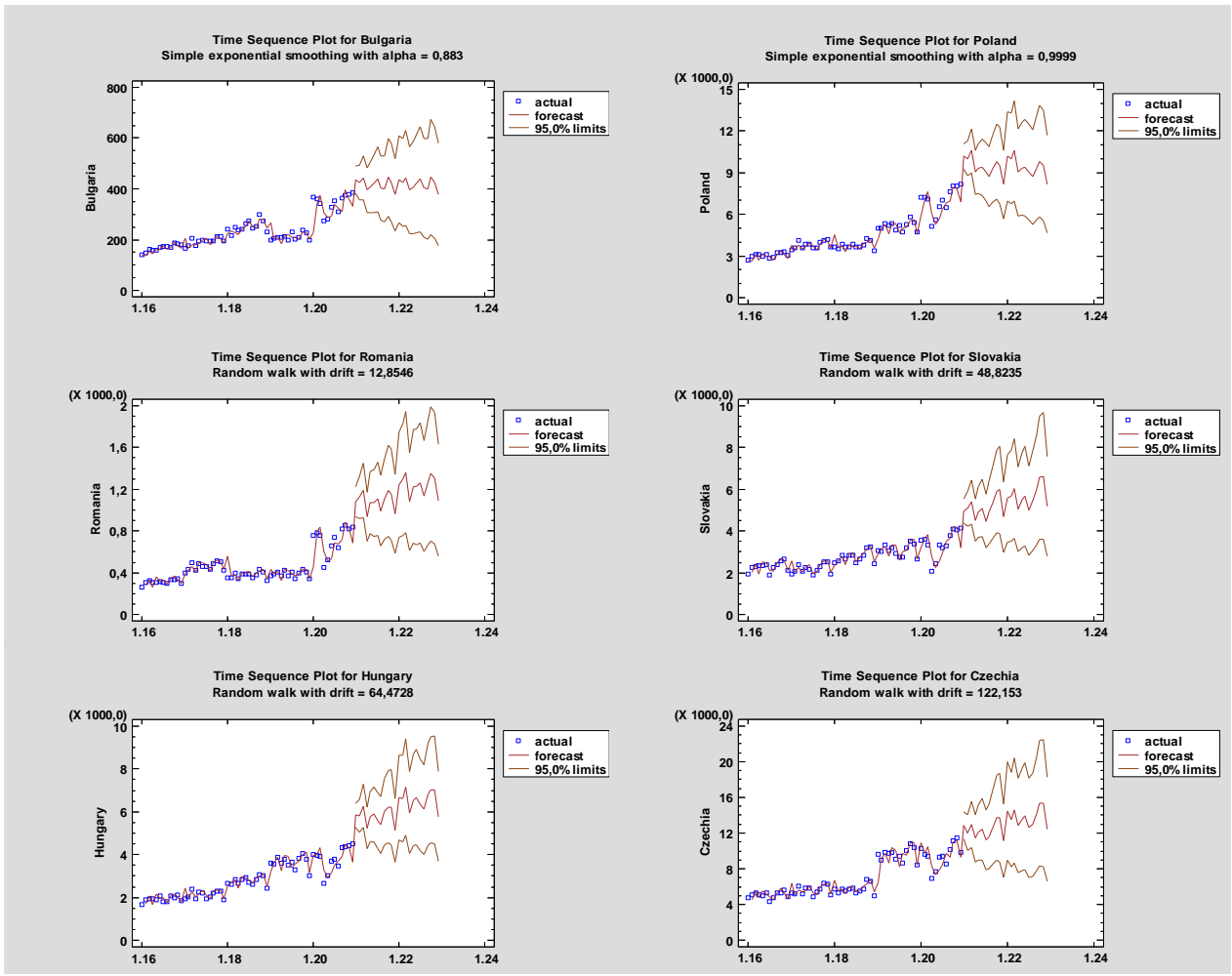

Source: Authors' calculations based on Eurostat Database (2020), Statista Database (2021)

Given the presented data, it should be noted that projected volumes of the VAT mobilization from e-commerce transactions in Eastern Europe in comparison with the mobilization of taxes and fees in these countries in 2019 suggest that the legislative changes will directly increase the level of tax revenue to the countries' budgets. It is essential in pandemic economic conditions (Casado, 2020; Shkarlet et al., 2019). Simultaneously, the VAT accumulation level from e-commerce transactions will be further determined by the number of customers, the overall level of profitability of a particular consumer, sales, business activity and the economy as a whole.

Table 2. Mobilization dynamics of the forecast VAT volumes in the second half of 2021 and 2022

\begin{tabular}{|c|c|c|}
\hline Country & The second half of 2021 & $\mathbf{2 0 2 2}$ \\
\hline Bulgaria & 5016,88 & 5152,75 \\
\hline Poland & 113022,09 & 113022,09 \\
\hline Romania & 12984,796 & 14835,87 \\
\hline Slovakia & 61263,4 & 68293,97 \\
\hline Hungary & 69431,09 & 78715,18 \\
\hline Czech Republic & 147954,1 & 165544,4 \\
\hline
\end{tabular}

Source: Own study based on Tradingeconomics Website (2020)

Although such legislative changes increase the tax burden on the final consumer and, consequently, lead to higher prices for products and services, e-commerce markets and tools will continue to improve their performance. Because e-commerce is economically diverse in its delivery of services, including intangible character by electronic means, it is difficult for fiscal authorities to administer tax payments. There many issues that need to be addressed and they determine the formation of a new tax environment.

Examining the analyzed issue, we conclude that the EU is creating a new ecosystem of tax administration and its component-the VAT sector for e-commerce, the author's vision, as it is demonstrated in Fig. 4. 
Figure 3. The share of projected VAT volumes from e-commerce in 2021-2022 in Eastern Europe

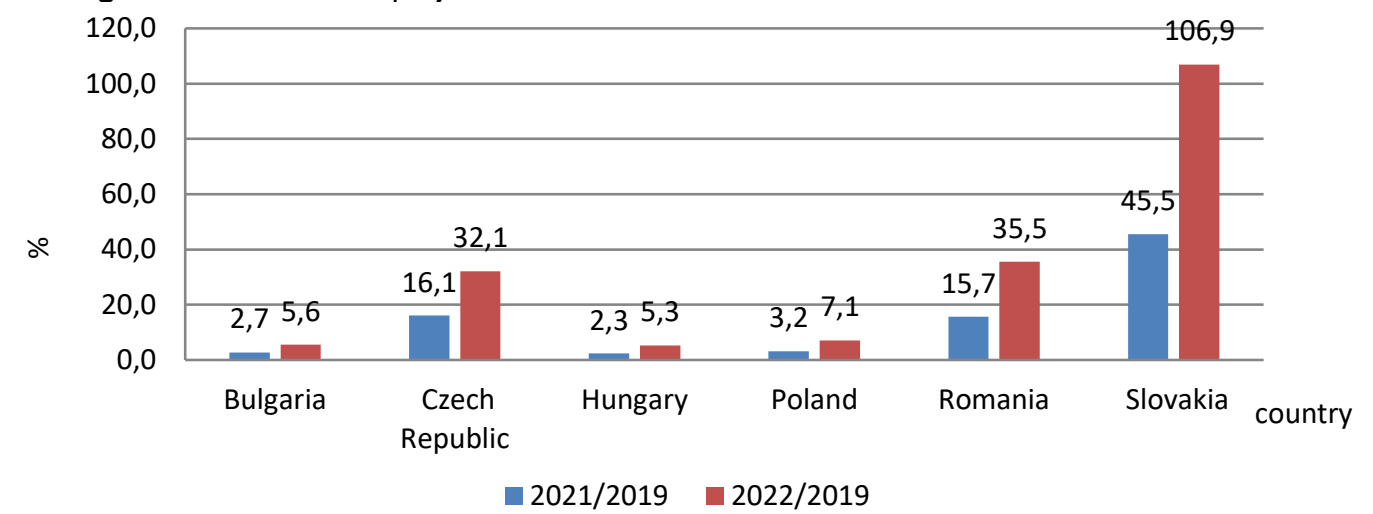

Source: Compiled by the authors on Eurostat Database (2020), Statista Database (2021), Tradingeconomics Website (2020)

Fig. 4 shows the formation of a consolidated digital tax environment of the EU, which determines the VAT administration's specifics in e-commerce transactions in these countries. The basis of its operation is the level of communication between the EU countries relating to cross-border transactions. As authors consider, this ecosystem's main task should be to accumulate information about the end of the B2C link (the end-user) and tax accounting of e-commerce transactions. All this can form the basis of cross-tax reconciliation of VAT. Banks act as essential intermediaries in the presented ecosystem as intermediaries in exchanging information and interim tax reporting.

Figure 4. VAT administration ecosystem

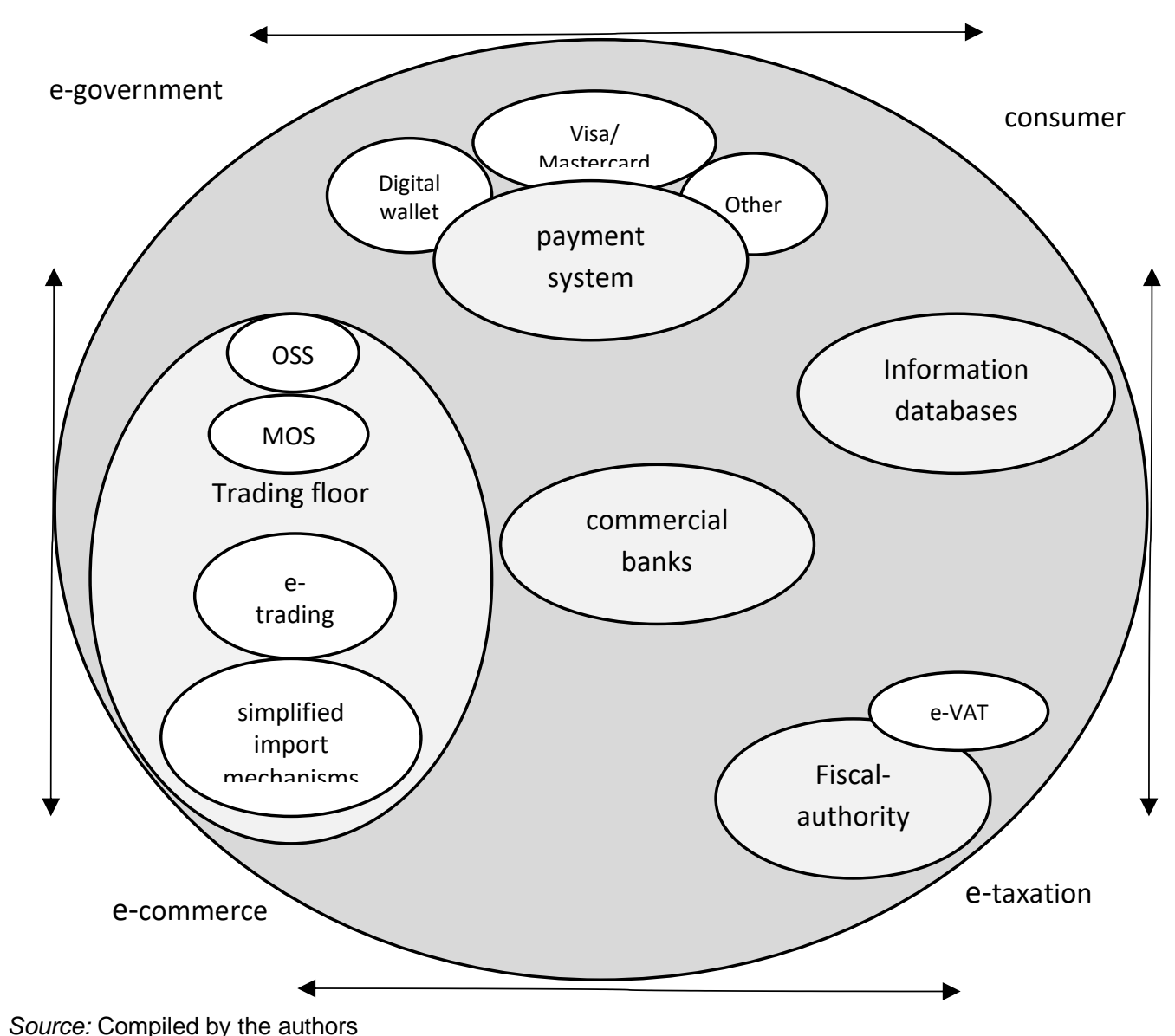

The presented tax space requires the regulation of e-commerce VAT administration to increase the level of effectiveness of the fight against tax fraud and tax evasion on such vectors of the roadmap to improve tax administration as: 
1) combating the underestimated customs value of e-commerce from non-EU countries (up to EUR billion per year);

2) tax cooperation arrangements between the EU Member States and non-EU countries, but with which the EU cooperates in the framework of e-commerce, are not fully agreed upon;

3 ) the inefficiency of compulsory VAT collection when crossing the customs border;

4) unification of the VAT tax reporting with the application of VAT rates of the country of the final consumer;

5) identification of sales from third countries and place of delivery to the final consumer;

6) mandatory payment of VAT with a lower threshold (EUR 22,00), despite the increase in the cost of this tax administration, given the increased administrative burden and compliance with the law for both fiscal authorities and taxpayers;

7) cooperation of fiscal authorities of the EU countries;

8) development and consolidation of the mini-single window (MOSS) functional responsibilities, the operation of the single window system (OSS) for the sale of goods and services from third countries.

These problems can be mitigated using the latest information technologies of monitoring and supervision, tracking e-commerce transactions' legality, and ensuring compliance with the tax obligation in the VAT mobilization process. The fiscal authorities' essential task should be to determine the rules of balancing revenues in the form of the accumulated VAT amounts with the administrative costs and compliance costs with strict following with the buyers' business data sellers' confidentiality requirements. The EU fiscal authorities should ensure the rules on tax transparency in digital platforms' operation by exchanging information, joint tax audits, and collective inquiries.

The main functionality of the tax ecosystem, in our opinion, should be designed for the responsibility of digital markets and platforms-the suppliers or operators of the electronic interface, because today, they are defined as the only way to improve the VAT administration at the maximum VAT accumulation. Digital platforms are designed to work closely with fiscal authorities in the process of exchanging information on intermediary transactions, and in some cases, to act as tax agents for sellers, subject to the institutional safeguards to prevent the misuse of private data. Suppose the digitalization processes in tax administration are appropriately used. In that case, it will be possible to reduce the administrative burden on both the taxpayers and fiscal authorities, increasing the business environment's tax efficiency in the digital age.

We believe that exclusively digital platforms in the current conditions of e-commerce in the EU and globally are essential.

Digital platforms are required to accumulate information about vendors operating on these platforms. The collection of a massive array of data requires creating a single electronic system for storing tax information and the joint accounting of the cross-border VAT liabilities on the principle of cloud technology. On the other hand, the digital platforms should be responsible for ensuring that sellers, who use their platforms, comply with tax obligations under new rules-they will have to collect and pay VAT on actual sales.

In this case, the exclusive role should be given to the functioning of special procedures -VAT-MOSS, OSS and IOSS (the mechanism of simplified imports). The IOSS must apply to imports from third countries as a supplier/ electronic interface operator and is obliged to calculate the VAT amounts on the sale of goods to declare and pay the globally estimated tax in the EU country that identifies the person. On the one hand, such rules will exempt the imported goods from VAT (reduce the volumes of customs clearance transactions). However, since under the IOSS, the VAT must be levied on the sales of goods-will increase the fiscal authorities' functional burden.

As part of improving the tax administration of VAT on e-commerce transactions, the issue of administrative cooperation agreements with the countries other than the EU, it is advisable to continue to work on improving the efficiency of control, VAT collection and the efficiency of the regulatory framework, in particular: 
1. The control over the implementation of requests to non-EU countries for agreements on mutual administrative assistance in e-commerce taxation is strengthened.

2. Inspection and control of the nature of the burden of the low and underestimated value of ecommerce trade flow (to legislate the concepts "production value", "market value" and "full value" of goods (works/services) sold in e-commerce) of the low value.

3. Assessment of the legality and performance of traders in the intra-European distance goods sales and MOSS.

4. Cooperation of Member States on a methodology for accessing the GAP VAT in e-commerce.

5. Study of the legality of the use of digital currencies in the calculations of e-commerce to increase the fight against VAT fraud in e-commerce.

6. Identification of the legality of the Member States' application of tax benefits of the agreed economic operators.

7. Audit activities in the field of MOSS should be conducted based on administrative cooperation.

8. Improvement of the VAT enforcement system of e-commerce transactions by agreeing on a common methodology for GSP determining e-commerce transactions.

\section{Conclusions.}

With the necessity of carrying out transformations in tax administration, the tax system's adaptation to the existing conditions of the permanent change of the economic environment is established. These facts require the European consolidation in the context of globalization and the development of new approaches to VAT administration to increase the fiscal efficiency of the EU national tax systems.

The results of this study were the deepening of the theoretical and applied provisions for the VAT administration improvement of e-commerce transactions in the context of global convergence of the national economic systems based on forecasting the future VAT volumes from e-commerce operations in Eastern Europe due to recent changes in the quarantine environment aimed at finding previously unused sources of the revenue of national budgets. The forecast calculations were made based on monthly volumes of e-commerce imports for 2016-2020 due to the econometric method of modeling - the time series forecasting. Due to the VAT base's obtained forecast indicators of e-commerce transactions, the calculation of future revenues of the studied tax was carried out. By calculating the VAT ratio as a share of total tax revenues, it is proved that VAT on e-commerce transactions is still an instrument of the macroeconomic influence on the formation of budget revenues.

The author's vision of the VAT administration ecosystem for e-commerce transactions determines the close and necessary interaction of the consumers, e-commerce, e-taxation, e-government in the framework of information exchange, tax audit, control and responsibility for tax compliance, tax payment and timely reporting. The critical role of digital platforms as tax agents of e-commerce participants is determined. The main tasks to be achieved should be the involvement of digital platforms in the VAT administration policy, the introduction of a single electronic form of VAT reporting in e-commerce transactions, and the exchange of tax information of all EU countries digital platforms as trade organizers. As a result, it will provide the prevention and early detection of e-commerce fraud in cross-border transactions. The starting points of the study can be used to forecast other tax payments in the process of their administration.

\section{References}

1. Agrawal, D., \& Fox, W. (2017). Taxes in an e-commerce generation. International Tax and Public Finance, 24(5), 903-926. https://doi.org/10.1007/s10797-016-9422-3

2. Andriyash, M. (2014). Problems of taxation of the value added tax of the EU Mem ber States. Actual problems of international relations, 122(1), 215-227. 
3. Aslam, A. \& Shah, A. (2017). Taxation and the peer-to-peer economy. International Monetary Fund. Working Paper No. 17/187.

4. Balcerzak, A. (2016). Fiscal Burden in the European Union member states. Economic Annals-XXI, 16 (9-10), 4-6. DOI: https://doi.org/10.21003/ea.V161-01

5. Büyükşahin, Ü.Ç., \& Ertekin, Ş. (2019). Improving forecasting accuracy of time series data using a new ARIMA-ANN hybrid method and empirical mode decomposition. Neurocomputing, 361, 151163. https://doi.org/10.1016/j.neucom.2019.05.099

6. Boiko, V., Kwilinski, A., Misiuk, M., \& Boiko, L. (2019). Competitive Advantages of Wholesale Markets of Agricultural Products as a Type of Entrepreneurial Activity: The Experience of Ukraine and Poland. Economic Annals-XXI, 175(1-2), 68-72. https://doi.org/10.21003/ea.V175-12

7. Bondarenko, S., Ivanchenkova, L., Okhrimenko, O., Zybareva, O., Karpitskaya, M., \& Huz, M. (2020). Risk management of enterprise restructuring strategy. International Journal of Advanced Research in Engineering and Technology, 11(5), 14-25.

8. Casado, M.G. (2020). The effect of fiscal stimulus: Evidence from COVID-19. Cambridge, MA: National Bureau of Economic Research. https://doi.org/10.3386/w27576

9. Cheng, L. (2011). Notice of Retraction: Tax administration in e-commerce: Base on B2C and C2C. International Conference on E-Business and E-Government (ICEE), 1-4. https://doi.org/10.1109/ICEBEG.2011.5882035

10.Czyżewski, B., Matuszczak, A., \& Miśkiewicz, R. (2019). Public goods versus the farm price-cost squeeze: shaping the sustainability of the EU's common agricultural policy. Technological and Economic Development of Economy, 25(1), 82-102. https://doi.org/10.3846/tede.2019.7449

11.Cosmulese, C.G., Socoliuc, M., Ciubotariu, M.-S., Mihaila, S., \& Grosu, V. (2019). An empirical analysis of stakeholders' expectations and integrated reporting quality. Economic ResearchEkonomska Istraživanja, 32(1), 3963-3986. https://doi.org/10.1080/1331677X.2019.1680303

12.Dubyna, M., Zhavoronok, A., Kudlaieva, N., \& Lopashchuk, I. (2021). Transformation of household credit behavior in the conditions of digitalization of the financial services market. Journal of Optimization in Industrial Engineering, 14(1), 97-102.

13.European Commission Database (2021). URL: https://ec.europa.eu

14.Eurostat Database (2020). URL: https://ec.europa.eu

15.Gamboa, A.M., \& Sophia, J. (2002). Development of tax forecasting models: Corporate and individual income taxes. PIDS Discussion Paper Series, 2002-06.

16.Gechert, S., Horn, G., \& Paetz, C. (2018). long-term effects of fiscal stimulus and austerity in Europe. Oxford Bulletin of Economics and Statistics, 3, 647-666.

17.Grigoraș-Ichim, C.E., Cosmulese, C.G., Savchuk, D., \& Zhavoronok, A. (2018). Shaping the perception and vision of economic operators from the Romania - Ukraine - Moldova border area on interim financial reporting. Economic Annals-XXI, 173(9-10), 60-67.

18. Helmuth, C., \& Gahvari, F. (2000). Tax evasion, fiscal competition and economic integration. European Economic Review, 44(9), 1633-1657.

19. Hodzic, S., \& Celebi, H. (2017). Value-added tax and its efficiency: EU-28 and Turkey. UTMS Journal of Economics, 8(2), 79-90.

20.International Monetary Fund Database (2021). URL: https://www.imf.org

21.Internet Usage in the European Union (2021). URL: https://www.internetworldstats.com/stats9.htm

22.Ivashchenko, A.I., \& Orlova, N.S. (2017). Comparative analysis of some EU and EU associated countries to identify the phenomenon of business development in post-socialist countries. Economic Annals-XXI, 163(1-2(1)), 22-25.

23.Jenkins, G., Kuo, C.-Y., \& Shukla, G. (2000). Tax analysisand revenue forecasting. Issues and 
Techniques. URL: https://cri-world.com/publications/qed_dp_169.pdf

24.Kesteren, G., Cornielle, S., \& Nellen, F. (2020). Fundamentals of the e-commerce VAT package ad van doesum (Maastricht University, PwC Netherlands, 's-Gravenhage Court of First Instance).

25.Kharazishvili, Y., Kwilinski, A., Grishnova, O., \& Dzwigol, H. (2020). Social Safety of Society for Developing Countries to Meet Sustainable Development Standards: Indicators, Level, Strategic Benchmarks (with Calculations Based on the Case Study of Ukraine). Sustainability, 12(21), 8953. https://doi.org/10.3390/su12218953

26.Kholiavko, N., Popova, L., Marych, M., Hanzhurenko, I., Koliadenko, S., \& Nitsenko, V. (2020). Comprehensive methodological approach to estimating the research component influence on the information economy development. Naukovyi Visnyk Natsionalnoho Hirnychoho Universytetu, 4, 192-199. https://doi.org/10.33271/nvngu/2020-4/192

27.Kholiavko, N., Shkarlet, S., \& Dubyna, M. (2015). Territorial reform in the system of strategic management of energy-economic and information spheres of the state. Economic Annals-XXI, 5-6, 103-107.

28.Khudolei, V., Bespalov, M., Tulchynska, S., Tulchinsky, R., \& Kholiavko, N. (2021). Fiscal stimulation of spatial development: the EU Countries' cases. Financial and credit activity: problems of theory and practice, $1(36), 124-132$.

29. Killington, K., \& Dylewski, P. (2017). VAT deduction and noneconomic activities: art or science? Tax Journal, 14-15.

30.Kovalenko, Y. (2013). Standards within the Code of Good Practice for financial activities. Actual Problems of Economics, 148(10), 8-14.

31.Kovova, I., Malyshkin, O., Vicen, V., Shulyarenko, S., Semenova, S., \& Shpyrko, O. (2018). Value added tax: effectiveness and legal regulation in Ukraine and the European Union. Economic AnnalsXXI, 171(5-6), 4-14. https://doi.org/10.21003/ea.V171-01

32.Kurniawan, T. (2018). Modernization of the tax administration system: a theoretical review of improving tax capacity. Web of Conferences, 73, 10022. https://doi.org/10.1051/e3sconf/201873

33. Kwilinski, A., Dzwigol, H., \& Dementyev, V. (2020). Model of Entrepreneurship Financial Activity of the Transnational Company Based on Intellectual Technology. International Journal of Entrepreneurship, 24 (Special Issue: Entrepreneurship, Innovation Management and Sustainability), 1-5. Retrieved from https://www.abacademies.org/articles/Model-of-Entrepreneurship-FinancialActivity-of-the-Transnational-Company-Based-on-Intellectual-Technology.pdf

34.Lagovska, O., Ilin, V., Kotsupatriy, M., Ishchenko, M., \& Verbivska, L. (2020). Priority directions of tax policy change in the information sphere. Naukovyi Visnyk Natsionalnoho Hirnychoho Universytetu, 3, 183-190. https://doi.org/10.33271/nvngu/2020-3/183

35.Lamensch, M. (2017). The principle of "substance over form» with respect to the exercise of the right to deduct input VAT - A critical analysis of the Barlis jurisprudence. World Journal of VAT/GST Law, 6(2), 129-137. https://doi.org/10.1080/20488432.2017.1407126

36.Lamensch, M. (2018). Adoption of the E-Commerce VAT Package: The Road Ahead Is Still a Rocky. EC Tax Review, 2(74), 186-195.

37.Liam, E., Keen, M., Bodin, J., \& Summers, V. (2001). The modern VAT. International Monetary Fund. Washington.

38. Lodin, S. (2002). What ought to be taxed and what can be taxed: A new international dilemma, in M. Govinda Rao, Editor, Development, Poverty, and Fiscal Policy: Decentralization of Institutions (Essays in honour of Raja J. Chelliah). New Delhi: Oxford University Press.

39.Louzis, D.P. (2019). Steady state modelling and macroeconomic forecasting quality. Journal of Applied Econometrics, 34(2), 285-314. https://doi.org/10.1002/jae.2657

40. Mattson, R. (1997). Electronic commerce: the challenges to tax authorities and taypayers discussion. URL: http://www.oecd.org/tax/treaties/1923232.pdf 
41.McLaren, J. (2013). Institutional Elements of Tax Design and Reform. The World Bank. Technical Paper No. 539. Washington.

42.Merkx, M. (2020). New VAT Rules for E-Commerce: The Final Countdown Has Begun, EC Tax Review, 29(4), 197-205.

43.Oliychenko, I., Shkarlet, S., Dubyna, M., Ditkovska, M., \& Zhovtok, V. (2020). Comparative analysis of best practices in e-Government implementation and use of this experience by developing countries. Administratie si Management Public, 34, 118-136.

44.Papis-Almansa, M. (2019). VAT and electronic commerce: the new rules as a means for simplification, combatting fraud and creating a more level playing field? ERA Forum 20, 201-223. https://doi.org/10.1007/s12027-019-00575-9

45.Piggott, J., \& Whalley, J. (2001). VAT Base Broadening, Self-Supply, and the Informal Sector. The American Economic Review, 91(4), 1084-1094.

46.Dzwigol, H., \& Dzwigol-Barosz, M. (2020). Sustainable Development of the Company on the Basis of Expert Assessment of the Investment Strategy. Academy of Strategic Management Journal, 19(5), 1-7.

47.Popelo, O., Shkarlet, S., Ivanova, N., Dubyna, M., \& Zhuk, O. (2020). Infrastructural and regional development: theoretical aspects and practical issues. Estudios de Economia Aplicada, 38(4). https://doi.org/10.25115/eea.v38i4.4002

48.Rini, E.S. \& Murwendah (2020). Taxing the Smart Retail: Value Added Tax Policy Analysis on Digital Transactions in Indonesia. 7th International Conference on ICT for Smart Society: AloT for Smart Society, 9307601, 1-7.

49.Rivza, B., Kruzmetra, M., Rivža, P., Miceikiene, A., Balezentis, A., \& Jasaitis, J. (2020). E-commerce as a Consequence of Innovation and the Cause of New Innovations for SMEs: the Perspectives of Latvia and Lithuania. Comparative Economic Research. Central and Eastern Europe, 23(3), 7-20. https://doi.org/10.18778/1508-2008.23.17

50.Saługa, P.W., Szczepańska-Woszczyna, K., Miśkiewicz, R., \& Chłąd, M. (2020). Cost of Equity of CoalFired Power Generation Projects in Poland: Its Importance for the Management of Decision-Making Process. Energies. 13(18), 4833. https://doi.org/10.3390/en13184833

51.Scarcella, L. (2020). E-commerce and effective VAT/GST enforcement: Can online platforms play a valuable role? Computer Law and Security Review, 36, 105371.

52.Shkarlet, S., Dubyna, M., Shtyrhun, K., \& Verbivska, L. (2020). Transformation of the paradigm of the economic entities development in digital economy. WSEAS transactions on environment and development, 16, 413-422. https://doi.org/10.37394/232015.2020.16.41

53.Shkarlet, S., Dubyna, M., Vovk, V., \& Noga, M. (2019). Financial service markets of Eastern Europe: a compositional model. Economic Annals-XXI, 176(3-4), 26-37.

54.Shkolnyk, I., Kozmenko, S., Polach, J., \& Wolanin, E. (2020). State financial security: comprehensive analysis of its impact factors. Journal of International Studies, 13(2), 291-309. https://doi.org/10.14254/2071-8330.2020/13-2/20

55.Spies, K. (2017). Fundamental freedoms and VAT: an analysis based on the Credit Lyonnais case. World Journal of VAT/GST Law, 6(2), 100-128.

56.Statista Database (2021). URL: https://www.statista.com

57.Tradingeconomics Website (2020). URL: https://tradingeconomics.com

58.Tymchenko, O., Sybirianska, Yu., \& Abramova, A. (2019). The approach to tax debtors segmentation. Ikonomicheski Izsledvania, 28(5), 103-119.

59.Vovk, V., Zhezherun, Y., Bilovodska, O., Babenko, V., \& Biriukova, A. (2020). Financial monitoring in the bank as a market instrument in the conditions of innovative development and digitalization of economy. Management and Legal Aspects of the Risk-Based Approach, 31(4), 559-570. https://doi.org/10.22068/ijiepr.31.4.559 
60.Woon Nam, C., Gebauer, A., \& Parsche, R. (2003). Is the completion of EU single market hindered by VAT evasion? CESifo Network: Promoting Economic Research, Cesifo Working Paper No. 974. URL: www.CESifo.de 